\title{
THE IMPACT OF DigITAL PlATFORMS AND SOCIAL MEDIA ON THE FREEDOM OF EXPRESSION AND PLURALISM IN SERBIA
}

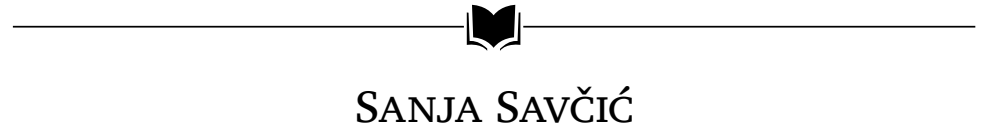

SANJA SAVČIĆ

\section{Introduction}

Communication is a natural human need. It is based on the inner and outer elements. The first concerns cognition and the thinking process, and the second refers to communicating information and formed opinions to others. Viewed in this way, communication is a continuous exchange of opinions, facts, and knowledge. This exchange is the basis for connecting but also separating individuals, groups, and even entire social communities. Essentially, such communication is the basis of civilizational achievements and social and political changes.

At the beginning of the $21^{\text {st }}$ century, social networks expanded in the communication domain. Among them, the most popular are Facebook, MySpace, Twitter, and TikTok. These and similar services have become part of a global trend within a very short time, even though most were initially established as university networks. At present, there are almost no Internet users who do not use at least one social network. The development of activities on social networks can be compared with the development of technologies with both high-processing power and the memory capacity for storing the vast amount of data exchanged via the Internet. New information technologies have enabled new ways of applying and communicating information. The development of social media has enabled the rapid dissemination of

Sanja Savčić (2021) The Impact of Digital Platforms and Social Media on the Freedom of Expression and Pluralism in Serbia. In: Marcin Wielec (ed.) The Impact of Digital Platforms and Social Media on the Freedom of Expression and Pluralism, pp. 111-140. Budapest-Miskolc, Ferenc Mádl Institute of Comparative Law-Central European Academic Publishing. 
information and interaction between users and the community. Apart from these digital advantages and besides the fact that the Internet has made daily life much more comfortable, the digital environment and the online environment in particular have put lawmakers in a very unfavorable position from the outset. The new environment has exposed traditional legal concepts' weaknesses and consequently raised a lot of questions. One pertains to freedom of expression and its exercise in the digital (i.e., the online) environment, especially through social networks.

The term 'social network' is most often defined as a social structure composed of individuals (or organizations) that are connected by one or more specific types of interdependence, such as values, visions, ideas, financial interests, friendship, kinship, common interests, financial exchange, sexual relations, or relations of trust, knowledge, or prestige. These virtual communities, which are available to all Internet users, enable fast communication and the exchange of various content, such as photos, videos, news, and events. Today, social networks are used by hundreds of millions of people worldwide. That has led to the creation of a new type of society, the so-called information society.

Bearing this in mind, there is no doubt that social networking's impact on modern life is extensive, but the question is to what extent this virtual world changes perceptions of modern society's recognized values. From the legal point of view, the most impacted area is the one regarding human rights, specifically the freedom of expression.

\subsection{Freedom of expression}

Freedom of expression is a first generation political and civil right. It includes all forms of expression: verbal (freedom of speech, as such), printed (freedom of the press), and artistic.

Freedom of expression was proclaimed in 1789 in the French Declaration of the Rights of Man and the Citizen as an inalienable right. Article 11 of this Declaration reads:

The free expression of ideas and opinions is one of the most precious human rights. Accordingly, every citizen can speak, write and print freely, but he will also be responsible for the abuse of this right, in the manner prescribed by law.

Freedom of expression is also protected by all international instruments dealing with the protection of human rights, and for the first time, it has been proclaimed via an international act, the Universal Declaration of Human Rights, ${ }^{1}$ which states that:

Everyone has the right to freedom of opinion and expression, including the right not to be disturbed by his opinion, as well as the right to seek, receive and impart information and ideas by any means and regardless of frontiers.

1 Adopted by the General Assembly of the United Nations, on 10 December 1948. 
Furthermore, this freedom, in addition to other civil and political rights, was proclaimed by the International Covenant on Civil and Political Rights, which was adopted by the General Assembly of the United Nations on December 16, 1966 . $^{2}$ Art. 19 states that:

Everyone has the right to freedom of expression. This right includes freedom to seek, receive and impart information and ideas of all kinds, regardless of frontiers, whether oral, written or printed, in the form of art or other media, or any other means of choice. The use of (these) freedoms (...) entails special duties and responsibilities. It may, therefore, be subject to certain restrictions which must nevertheless be expressly provided for by law and which are necessary for: a) respect for the rights and reputation of other persons; b) protection of national security or public order, or public health or morals.

Apart from the fact that freedom of expression is a right in itself, it is an indivisible element of other rights, such as political rights, rights of education, intellectual property rights, etc., or the means of their exercise. From that point of view, the passive holding of the state is not enough to render this right effective. It is equally important to provide complete protection for this right and enable information exchange.

\subsection{Freedom of expression and digital platforms - Introductory remarks}

Social media, including social networks and the Internet in general, are a convenient arena for this exchange. In terms of law, it is the realization of two mentioned rights: to express thoughts and to be informed. ${ }^{3}$ Keeping the nature of the Internet in mind, it is not incorrect to say that social networks comprise a virtual arena of freedoms, intensified by the fact that the laws, rules, and regulations that often govern us in real life are unclear, inapplicable, or absent.

Even though social networks have emerged as technical platforms and digital spaces for their users, they have become much more than that, and in so doing, are much closer to the term 'media.' Their improved function has been recognized through attempts to self-edit content. This corresponds with users' active role. In addition to providing only an information structure for information exchange, their visibility and distribution, alongside numerous abuses, have led to the question of how to edit. The need to edit something leads social networks into the world of media. Content on social networks, which is created by the users themselves, has become public space and exerts an influence on public opinion.

However, unlike the media, content on social networks is created by users, that is, ordinary citizens, with no real sensibility for the seriousness of and consequences 
associated with the opinions they express or the information they share. Their contributions are simply raw. Following the increasing incidence of mistreatment, the need to introduce conditions of use that could curb hate speech, insults, and threats has arisen. This is obviously the case when it comes to the prevention of abuse and harassment and the safety of children, who are especially vulnerable. Therefore, the question is: Who should edit the content distributed on social networks, i.e., who is supposed to be tasked with controlling it?

As regards social networks, self-regulation is offered as well, but it is not enough. There are at least three reasons for this remark. Firstly, it is impossible to ignore the fact that the companies that own and manage the infrastructure and enact regulations do not have influence over the users who create the content independently. Even if this was not the case, companies are naturally disinterested in setting unpopular rules that could repel users from social networks. Secondly, public opinion on social networks is of public interest and is therefore important to the authorities. Finally, the Internet erases state boundaries, while companies are subject to a particular country's legal system. That leads to the conclusion that countries cannot protect public interest, since companies do not have to be under state jurisdiction. Hence, it is crucial for authorities to intervene via state regulation.

This chapter will observe to what extent Serbian law can respond to the challenges of modern virtual society and preserve traditional human rights. For this purpose, the legal framework for freedom of expression, as well as its limitations, will be introduced. Afterward, methods of monitoring Internet content pursuant to various legal acts will be offered.

\section{Legal aspects of content censorship on social networks in Serbia}

\subsection{Introductory remarks}

In modern society, information is the most dominant commodity on the market, as well as in politics, national safety, culture, and science. However, information itself is neutral. From that perspective, the information must be available in order to be used. The provision and exchange of information form the core of communication. However, freedom of expression is the basis for enabling information exchange.

Freedom of expression includes all forms of expression: verbal (freedom of speech, as such), printed (freedom of the press), and artistic. In that sense, each modern and democratic country has an obligation to refrain from actions that could obstruct the exercise of this freedom through censorship or other restrictions. Apart from the fact that freedom of expression is a right in itself, it is an indivisible element of other rights, such as political rights, rights of education, intellectual property rights, 
etc., or the means of their exercise. From that point of view, the passive holding of a country is insufficient to render this right effective. It is equally important to provide complete protection for this right and enable information exchange.

\subsection{Freedom of expression in Serbia}

Art. 46 of the Constitution of the Republic of Serbia states that the freedom of thought and expression shall be guaranteed, as well as the freedom to seek, receive, and impart information and ideas through speech, writing, art, or in some other manner. Freedom of expression may be restricted by the law if necessary to protect the rights and reputation of others, to uphold the authority and objectivity of the court, and to protect public health, the morals of a democratic society, and the national security of the Republic of Serbia. ${ }^{4}$ On the other hand, freedom of thought, as an internal psychological process, cannot be limited by law, since that process is out of cognition and hence outside the authorities' control. ${ }^{5}$

Further, in Art. 50, titled Freedom of the media, the Constitution of the Republic of Serbia states that everyone shall have the freedom to establish newspapers and other forms of public information without prior permission and in a manner defined by the law that regulates the particular matter. The same applies to the establishment of television and radio stations.

Censorship shall not be applied in the Republic of Serbia (Art. 50(3)), but prevention of the spreading of information through means of public informing is not excluded. That may happen only when a competent court finds it necessary. In accordance with the principles of democratic society, a justified aim is to prevent inciting the violent overthrow of the system established by the Constitution or to prevent the advocacy of racial, ethnic, or religious hatred fueling discrimination, violent hostility, the exercise of the right to correct false, incomplete, or inaccurately imparted information resulting in the violation of any person's rights or interests, and the right to react to communicated information (Art. 50(4)).

Shaping an opinion that is supposed to be published depends on the facts the person has obtained. From that perspective, freedom of thought and expression as well as freedom of the media are as important as the right to be informed. Hence, the Constitution of the Republic of Serbia contains an explicit provision that guarantees everyone the right to be informed accurately, fully, and in a timely manner about matters of public importance. The media shall have the obligation to respect that right (Art. 51(1)). When it comes to the information kept by state bodies and organizations with delegated public powers, the right to access information shall be exercised in accordance with the specific law (51(2)).

4 Ustav Republike Srbije (Constitution of the Republic of Serbia), Official Gazette of the Republic of Serbia, No. 98/2006, dated on 8 November 2006. English version of the Constitution is available at: https://www.propisi.pravno-informacioni-sistem.rs/content.php?id=800.

5 Orlović, 2019, p. 90. 
Taking the provisions of the highest legal act into account, it is clear that freedom of expression, coupled with the correlated right to information, is not an unrestricted right. In general terms, those rights could be restricted by law, if the Constitution permits such restriction, for the purpose allowed by the Constitution, and to the extent needed to meet the constitutional purpose of restriction in democratic society without encroaching upon the substance of the relevant guaranteed right. The attained level of human and minority rights may not be lowered.

As relevant provisions provide, freedom of expression, in a broad sense, shall not endanger rights that promote higher values, that is, the rights and reputation of others, as well as the protection of national security, public order, public health, and morals. On the relevance of those rights regarding the individual's dignity, reputation, and honor, it can be testified that freedom of thought and expression is among the rights that cannot be derogated during war or state of emergency (Art. 202(4)).

\subsection{Restrictions on freedom of expression}

The Constitution of the Republic of Serbia protects freedom of expression as a fundamental right, but it also constitutes a framework for its restriction. In that sense, freedom of expression could be limited by others' rights and reputation and the obligation to uphold the authority and objectivity of the court and protect public health, the morals of democratic society, and the national security of the Republic of Serbia (Art. 46(2)).

This general provision, in fact, has the same meaning as Art. 10 of the European Convention of Human Rights. In that sense, the general provision restricting the freedom of expression has two mutual functions. One is the state's duty to enable any citizen to express their opinion without fear of being punished for it or being put in a different position compared to the unlike-minded. It also includes the accessibility of someone's expression. The other one is the state's duty as well, but it refers to the duty to protect the rights of others.

In order to fulfil both aims, the provisions of several laws prescribe certain content that could result in the violation or jeopardization of others' rights. These are not numerus clausus cases. In that sense, if the content is not explicitly recognized as inappropriate, this does not mean it is allowed. In fact, the court that will decide on eventual disputes determines whether the expressed content violates someone's rights or which one of the confronted rights requires protection in a specific situation.

According to a survey on rights violations on the Internet, ${ }^{6}$ the most frequent violations are in relation to threatening content, compromising security, insults, and

6 The research was conducted by the Share Foundation through continuous monitoring of violations in online communication. Results in different categories of monitoring are available at https://monitoring.labs.rs/. 
unfounded accusations. ${ }^{7}$ The affected parties are mostly citizens. However, the reverse is also true, as citizens comprise the majority of attackers. Other analyses consider regional rights violations in the digital environment. The results show that hate speech and discrimination are involved in almost half of the reports of Internetbased digital violations. ${ }^{8}$

Various actions and content could represent the violation and jeopardization of human rights, national security, and the morals of democratic society, but at the same time, this content represents the line between freedom of expression and expression that is punishable by law.

For the purpose of understanding the restriction of the freedom of expression, violations that are prevalent among unlawful actions committed on the Internet will be explained.

\subsubsection{Threatening content and compromised security}

Content that contains threats to attack another person's life or body could endanger that person's safety. In order for Internet content to be considered dangerous, it must cause fear in the person to whom it is directed, but it must also be directly stated and achievable. In each case, a competent body (usually a court) must determine whether these conditions are met. It is not always easy to correctly determine whether something is an expression of thoughts that are appropriate to jeopardize someone's right (because of a lack of seriousness). Moreover, it is sometimes not obvious which expression among similar ones has the potential to endanger someone's safety, which one causes fear, and finally, whether the attacked person is too sensible for the content. All relevant issues should be evaluated according to the circumstances of the particular case.

7 There are seven different categories of digital right and freedom breaches and several sub-categories under each that have been under monitoring: 1 ) information security breaches, including making content unavailable through technical means, destruction, and the theft of data and programs, computer fraud, unauthorized access - unauthorized alterations and insertions of content, disabling control over an online account or content; 2) information privacy and personal data breaches (publishing information about private life, illegal interception of electronic communications, breaches of citizens' personal data, illegal personal data processing, breaches of information privacy in the workplace, other breaches of information privacy); 3) pressures because of expression and activities on the Internet (publishing falsehoods and unverified information with the intention of damaging another's reputation, insults and unfounded accusations, threatening content and endangering of security, hate speech and discrimination, freedom of expression on the Internet and the workplace, pressures because of publishing information); 4) manipulation and propaganda in the digital environment (creating fake accounts and paid promotion of false content, content manipulation and organized reporting on social media; changes to or removal of content that is in the public interest; placement of commercial content as news, other manipulation in the digital environment); 5) holding intermediaries liable (pressures because of user-generated content); 6) blocking and filtering of content (blocking/filtering on the network level, algorithmic blocking or suspension of content); 7) other breaches of digital rights and freedoms not included in the categories previously defined. Available at: https://monitoring.labs.rs/.

8 Data available at: https://monitoring.bird.tools/. 
To illustrate, the Supreme Court of Serbia, in a decision during a criminal procedure, stated that the defendant, as one of the members of a group advocating violence against individuals belonging to the gay population or organizing a public gathering, sent a threat, the meaning of which was the deprivation of life or at least bodily injury of the participants in an event. The threat was sent through an electronic medium intended for the general public. That means that the threat was available to everyone, that is, a wide range of people, including the mentioned persons to whom the threat was addressed in a certain place. Bearing this in mind, the threat, given the specified circumstances under which it was addressed and could have been known, could objectively create anxiety, insecurity, and fear regarding the personal safety of the members of that circle of persons, who, as passive subjects and possible victims, are indicated in the indictment, in a manner that sufficiently identifies them as members of the target group to which the threat is addressed. ${ }^{9}$

Notwithstanding the outcome of the above case, the court indicates which elements of any statement made on the Internet, on a social network to be precise, are relevant to making the decision.

\subsubsection{Insults and unfounded accusations}

Expressions on the Internet that violate others' reputation and honor shall be considered unlawful. However, expressions with a negative connotation are not themselves enough to jeopardize someone's right to dignity, reputation, and honor. Devaluing the attacked person is an important element of violation. For that reason, the person toward whom the insult is directed has to be determined. In addition, the statement ought to be insulting according to objective criteria (such as the behavior of the society or group, common opinion on the quality of the statement, and the moral values of the particular group or society), not just the insulted person's perception. ${ }^{10}$

Insults occurring in the media or in the public forum are a qualified crime, and hence stricter punishment is handed down. ${ }^{11}$

\subsubsection{Hate speech and discrimination}

The Republic of Serbia's Constitution and laws prohibit discrimination. Moreover, it seems that much attention is paid to the violation of others' rights, especially the right of equity. On one side, the reason for this treatment is the fact that equity is a

9 Judgement of the Supreme Court of Serbia, Kzz 59/11, dated 31 August 2011.

10 In Lepojić vs. Serbia, and Filipović vs. Serbia, the European Court of Human Rights stated that authorities have a duty to suffer stronger criticisms and insults, and they need to be much more tolerant than ordinary citizens. This statement was contrary to the opinion of Serbian courts, which claimed that the honor of the authorities is more important than the same personal right of others. Kršikapa, 2008, p. 3.

11 Art. 170, par. 2 Criminal Code of the Republic of Serbia, Official Gazette of the Republic of Serbia, No. 85/05, 72/09, 111/09, 121/12, 104/13, 108/14, 94/16, 35/19. More on this: Petrašinović, 2020, pp. $469-481$. 
precondition of the exercise of other human rights. ${ }^{12}$ There is no value in protecting freedom of religion, for example, if religions are not treated equally by the competent law or in practice. The other reason for this legally developed restriction of freedom of expression is the divergence of behavior or content that could result in discrimination.

According to the Law on Prohibition of Discrimination of the Republic of Serbia, ${ }^{13}$ discrimination is any unjustified differentiation, inequitable conduct, or misconduct in relation to persons or groups or members of their families or persons close to them, directly or indirectly, if this behavior is based on race, color, ancestry, citizenship, nationality or ethnic origin, language, religious or political beliefs, gender, gender identity, sexual orientation, property status, birth, genetic characteristics, health status, disability, marital or family status, conviction, age, appearance, membership in political, trade union, and other organizations, and other real or assumed personal characteristics. ${ }^{14}$

As could be concluded from the definition provided in the mentioned provisions, discrimination can be conducted in any way and can be based on any personal characteristic. The condition that must be met in order to consider an active or passive behavior inequitable is unjustified differentiation among citizens. In the context of this work, the terms 'justified' and 'unjustified' will not be explained. Attention will be paid to the specific manifestation of discrimination through the exercise of freedom of expression. It is related to hate speech.

With the development of the Internet and social networks, opportunities for spreading intolerant, discriminatory, and hateful content have become greater. Bearing this in mind, legal and institutional mechanisms for grappling with communicative aggression on the Internet have been developed during the last decades and within the current century in general. ${ }^{15}$ The Law on Public Information and Media from 2014 and the Code of Journalists of Serbia define the media's obligation to edit all content contained in their publications, including readers' comments below the texts on online portals. The media are obliged to beware of and prevent the spread of hate speech and aggressive communication through its publications. Social networks, forums, and other online platforms, however, are not subject to these rules, and it is more difficult to edit discriminatory content and take measures against creators of hate speech.

The fact that hate speech is regulated by several laws illustrates Serbian society's sensibility with regard to the consequences of destructive communication. In that sense, breach of the prohibition of hate speech, as a specific kind of discrimination, is treated differently in comparison to other human rights breaches.

12 Etinski, 2013, pp. 51-67; Etinski, 2005, pp. 325-352.

13 Official Gazette of the Republic of Serbia, No. 22/2009.

14 Mršević, 2014, pp. 13-16.

15 Intensive anti-discriminatory action has been expected after conflicts in the Balkans region. For more on the development of the anti-discriminatory approach: Saša Gajin (ed.), 2010; Zubčević et al., 2017; Reljanović, Matić, and Ilić, 2010; Saša Gajin (ed.), 2015; Rašević, 2014. 
Specifically, apart from the criminal offense that includes hate speech as a substantial element of the crime, the protection the general anti-discriminatory law provides should be implemented in the dispute via the court decision.

Specific rules are applied in discrimination disputes. Fault for breach (intention or negligence) is not required for the determination of hate speech. The only claim in which fault is relevant is damage compensation. In that case, the absence of the intention to spread or encourage hate, aggression, or violence can release someone from the liability to compensate for damages. This is not the case in other claims. ${ }^{16}$

Further, regarding civil protection, the essential difference between the procedure for protection against discrimination and hate speech according to the Law on Prohibition of Discrimination and the procedure according to the Law on Public Information and Media $^{17}$ is reflected in passive legitimacy, i.e., the person against whom the request is directed. Whereas according to the Law on Prohibition of Discrimination, the protection of the endangered or violated right to equality is implemented via a demand directed against the discriminator, in lawsuits under the Law on Public Information and Media, the demand is directed against the editor-in-chief of the media publication. ${ }^{18}$ The editor-in-chief's liability arises from their responsibility for the content they edit. This is regardless of who authored the information, whether they are a journalist or someone else. In other words, the editor-in-chief's responsibility exists not only when the author of the information is a journalist, but also when the hate speech published in the media comes from others. In online media publications, indiscriminate publication of readers' comments on a certain topic in which the ban on hate speech is violated is not rare. ${ }^{19}$

Protection under criminal law is narrower because the criminal offense exists in cases of inciting national, racial, and religious hatred and intolerance. ${ }^{20}$ The offender's guilt depends on proving that their intent in this case was aimed at inciting religious hatred and intolerance among nations. To be precise, the fact that there was a verbal or physical attack on another people, nationality, ethnic community, or religion does not mean that the subjective (and substantial) element of this crime has been demonstrated.

16 According to Art. 43 of the Law on Prohibition of Discrimination, through a lawsuit, the plaintiff may demand: 1) imposing a ban on an activity that poses the threat of discrimination, a ban on proceeding with a discriminatory activity, or a ban on repeating a discriminatory activity; 2) that the court should establish that the defendant has treated the plaintiff or another party in a discriminatory manner; 3) taking steps to redress the consequences of discriminatory treatment; 4) compensation for material and non-material damage; 5 ) that the decision passed on any of the lawsuits referred to in previous items be published.

17 Law on Public Information and Media, Official Gazette of Republic of Serbia, No. 83/2014, 58/2015, $12 / 2016$.

18 Art. 103 of the Law of Public Information and Media.

19 Rašević, 2018, pp. 1309, 1310.

20 Art. 128 of the Criminal Code. 


\subsubsection{Breach of the right to privacy}

Disclosure of personal data, details about private life, photos, and other information without the concerned person's consent violates the right of privacy. ${ }^{21}$ This right is a focus of modern legislature, precisely because of the increased incidence of uncontrolled use of gathered personal information. In most cases, it is about abuse.

The increasing popularity of the Internet, especially social networks, has led to a more intensive consideration of privacy protection. Specifically, social network websites contain user information such as age, relationship status, income, and information about close family members, as well as registered users' addresses. The most common abuses and violations of privacy using data available on social networks are identity theft and the manipulation of personal data, which are related to employment and the misuse of photos on the Internet. ${ }^{22} \mathrm{~A}$ large number of social network services store personal data about users, so that users do not have to reenter them when they want to use them later, e.g., for online shopping, booking over Internet sites, or simply revisiting the same website. ${ }^{23}$

Simultaneously with the development of artificial intelligence and machine learning, expectations regarding the appropriate improvement of the legal instruments pertaining to personal data protection have arisen. Ethical issues arising from the application of artificial intelligence are a special aspect of the human rights debate amidst the so-called Fourth Industrial Revolution. This seems to be even more dominant if the fact that humans spend the majority of their daily lives under a certain type of (in)direct monitoring, intentionally or spontaneously, is considered. Smart devices connected to the Internet, the network of public and private surveillance cameras, and automated decision-making based on online behavior history are just some of the currently recognized sources of dispute between citizens, public policy, and industry.

The misuse of photos on the Internet is a form of privacy violation that occurs when photos from social network users' accounts are used and displayed without their consent. A photo of any person can be displayed in a way that may harm them on a personal level. Over time, social network users could download the photo, resulting in a large number of users having an opportunity to see the photo, share it, or even worse, make a photomontage that could be further misused. In addition, some social networks (e.g., Facebook) note in their terms of use that they reserve the right to publish user information or share it with other companies, lawyers, courts, government agencies, etc., if deemed necessary. ${ }^{24}$

21 Judgement of the Court of Appeal in Belgrade, Gž3 77/18, as of 29 March 2018.

22 Identity theft consists of the unauthorized use of personal data (date of birth, current residence, telephone number, occupation, friends, personal pictures), which have become publicly available. Identity theft on the Internet is a form of fraud committed by computer users involving gathering personal and financial information through a fake e-mail or website. Đukić, 2017, pp. 99-116.

23 Midorović and Sekulić, 2019, pp. 1158-1159.

24 Diligenski and Prlja, 2018, pp. 27-31. 
In this context, children are a particularly vulnerable category, and for this reason, wide, decisive action on the part of competent bodies is more than welcome.

\section{Controlling Internet content}

In order to protect individuals' human rights and the core issues of state and public interest, a degree of control over expression is necessary, in line with the constitutional purpose. However, since the Constitution explicitly prohibits censorship, a further explanation will be given as to what kind of control Serbian law provides.

Censorship, as an administrative procedure that precedes the announcement or publication of information, is uncommon in the modern world, and it is against the fundamental principles of modern human rights in democratic societies. However, abridgement does not always depend on an official government decree, injunction, or licensing decision. ${ }^{25}$ Many governmental measures may have the effect of abridging freedom of thought and expression. In this subsection, those regulated by relevant laws will be examined.

\subsection{Registration of media}

As previously mentioned, freedom of the media allows everyone the option to establish newspapers and other forms of public information, without prior permission. Serbian law mainly regulates public information services and public media. With respect to that, this paper will focus on those that are operable for freedom of thought and expression and freedom of the media.

First, there is the Law on Public Information and Media. According to this act, public information is provided by the media. ${ }^{26}$ The aim of the legal provisions is to obtain and protect the presentation, receipt, and exchange of information, ideas, and opinions through the media in order to promote the values of a democratic society, prevent conflicts and preserve peace, disseminate truthful, timely, credible, and complete information, and enable the free development of the individual. ${ }^{27}$

This law regulates the manner of exercising the freedom of public information, which includes, in particular, the freedom to collect, publish, and receive information, the freedom to form and express ideas and opinions, the freedom to print and distribute newspapers, and the freedom to produce and publish audio and audio-visual media services, information, and ideas through the Internet and other 
platforms, as well as the freedom to publish media and conduct public information activities. ${ }^{28}$

The term 'media' is defined as a means of public information that conveys editorially formed information, ideas and opinions, as well as other content intended for public distribution and an indefinite number of users in words, images, or sound. ${ }^{29}$ The term 'media' under this law excludes platforms, such as Internet forums, social networks, and other platforms that facilitate the free exchange of information, ideas, and opinions among its members, or any other independent electronic publication, such as blogs, web presentations, and similar electronic presentations; unless they are registered in the Media Register, they are not considered to be media under this law. ${ }^{30}$ Consequently, the provisions of the Law of Public Information and Media are not applicable to unregistered entities (i.e., inapplicable to social networks).

From the perspective of the freedom of expression, several advantages could be recognized through registration. ${ }^{31}$

Journalists are not obligated to reveal their information sources, except where the information refers to a criminal act or the perpetrator of a criminal act for which a sentence of imprisonment of at least five years is prescribed by law and if the information cannot be obtained in any other way. ${ }^{32}$ Otherwise, such an obligation exists. Furthermore, for some criminal acts, stricter punishment is stipulated if the victim is a journalist associated with registered media. ${ }^{33}$ This should

28 This law also regulates the principles of public information, public interest in public information, the provision and distribution of funds for public interest, imprint, abbreviated imprint and identification, the publicity of media data and the Register, the protection of media pluralism, the position of editors, journalists, and representatives of foreign media, media distribution, temporary storage and insight into the media record, special rights and obligations in public information, personal information, the means and procedures of legal protection, supervision over the application of the provisions of the law, and penal provisions. Art. 3 of the Law on Public Information and Media.

29 Art. 29 of the Law on Public Information and Media.

30 Art. 30 of the Law on Public Information and Media. The Media Register is maintained by the Business Registers Agency of the Republic of Serbia (hereinafter, 'the Agency') in accordance with the law governing the legal position of the Agency and the law governing the registration procedure with the Agency and this law (Art. 37 of the Law on Public Information and Media.). Natural and legal persons, domestic and foreign, have equal rights to publish and other rights pertaining to publishing, in accordance with law and signed international agreement (Art. 11 of the Law on Public Information and Media.). In case law: Decision of the Court of Appeal in Belgrade, Gž. 216/18, as of 21 December 2018.

31 Naturally, there are consequences. According to the provision of Art. 44, the Republic of Serbia, Autonomous Province and a local self-government unit, as well as an institution, a company or another legal person whose majority shareholder is the state, or which is entirely or predominantly funded from public revenue may not co-finance projects of or in any other way allocate state aid to a medium or a publisher not entered in the Register. The Republic of Serbia, Autonomous Province and a local self-government unit, or an institution, company or another legal person whose majority shareholder is the state, or which is entirely or predominantly funded from public revenue may not advertise in or use other services of unregistered media.

32 Art. 52 of the Law on Public Information and Media.

33 Art 138 of the Criminal Code. 
act preventively, since strong punishment could deter potential perpetrators. On the other hand, if journalists associated with registered media have committed such a crime, they could be released of punishment if they believed in the truthfulness of the distributed information. ${ }^{34}$ Other perpetrators would be punished even if they prove that the information is true. ${ }^{35}$

Within the area of civil law, editors and journalists have an obligation to check the information's origin, truthfulness, and completeness before releasing a publication that contains information about a certain phenomenon, event, or person. Apart from the fact that the journalist must be proven to be at fault, unlike the presumption under the general rules of tort law, all other aspects can be considered stricter than the general rules of damage compensation. In that sense, and because of this, an editor-in-chief is responsible for that medium. An editor responsible for a specific issue, section, or program unit shall be responsible for the content they edit. ${ }^{36}$ This liability is not just for content that the editor chooses and directly controls, but also for readers' comments as well. ${ }^{37}$

Apart from the special treatment of registered media, the Law of Public Information and Media includes provisions that specifically protect media pluralism. One of the relevant issues is the Media Register, since its purpose is to provide the public with information about the media. ${ }^{38}$ It seems justified to enable citizens to form their own opinions about the authenticity and reliability of information, ideas, and opinions published in the media to facilitate the identification of the media's possible influence on public opinion and protect media pluralism. ${ }^{39}$ However, the provisions pertaining to the protection of media pluralism are more important. ${ }^{40}$

In that sense, a threat to media pluralism in the case of printed media shall be identified by the ministry responsible for information, and if there is the merging or cross-acquisition of shares, where at least one electronic medium is involved, the

34 Art. 173-175 of the Criminal Code.

35 Art. 172 of the Criminal Code.

36 Art. 48 of the Law on Public Information and Media.

37 Judgement of the Court of Appeal in Belgrade, Gž3 137/19, as of 21 August 2019.

38 Art. 38 of the Law on Public Information and Media.

39 Art. 7 of the Law on Public Information and Media. Therefore, media registration does not depend on the decision process in terms of the authorities' jurisdiction, but rather in terms of public information. Hence, registration can only be rejected if the application does not fulfil the formal conditions (Art. 17 Law on the Procedure of Registration in Business Register Agency, Official Gazette of Republic of Serbia, No. 99/2011, 83/2014 и 31/2019.). Otherwise, the registrar will register the media. According to available data, there are 2,642 active media in Serbia. Available at: https://bit. ly/3kp5oxc. Registration, however, is not necessarily permanent. Media should be deleted following a publisher's notice, or the registrar, acting in an official capacity, shall delete the medium from the Register based on the decision of the responsible authority referred to the protection of media pluralism, following the deletion of the publisher from the Register where it was entered into or for any other reason stipulated under a special law (Art. 41 Law on Public Information and Media). See more on this topic: Rakib, 2014, pp. 337-349.

40 Art. 6, and 45-47 of the Law on Public Information and Media. 
threat shall be identified by an independent regulatory body, in accordance with the law regulating electronic media. ${ }^{41}$ The ministry responsible for information shall initiate the procedure, and whenever it is established that media pluralism has been threatened, the strictest measure that can be levied on an entity is the medium in question's deletion from the Register. In that case, the entity loses its media status and consequently is not in the capacity of the Law on Public Information and Media. ${ }^{42}$

When it comes to electronic media, the situation regarding controlling media is different. Specifically, the Law on Electronic Media ${ }^{43}$ stipulates, in accordance with international conventions and standards, the organization and operation of a regulatory body for the electronic media, conditions and the manner of providing audio and audiovisual media services, conditions and procedures for issuing licenses for the provision of audio and audiovisual media services, and other issues relevant to the field of electronic media. ${ }^{44}$ Social networks are not covered by its provisions.

The regulatory body for electronic media is an independent regulatory organization, that is, a legal entity that exercises public authority for the purpose of, among others, contributing to the preservation, protection, and development of freedom of opinion and expression..$^{45}$ Within the scope of its work, the regulator controls media service providers ${ }^{46}$ operation and ensures the consistent application of the provisions of the relevant law, imposes measures upon media service providers, and decides on complaints in connection to media service providers' programming activities. ${ }^{47}$

Examining controls on media service providers' operation, the regulator observes whether such operation reflects the consistent implementation and improvement of the principles underlying the regulation of relations in the field of electronic media and immediately applies the required measures. Such control pays special attention to media service providers' compliance as it regards the program content they are licensed to broadcast. The regulator, before a competent court or other public authority, shall initiate proceedings against the media service provider

41 Art. 47(1) of the Law on Public Information and Media.

42 Moreover, a fine of between RSD 100,000 and 1,000,000 for a commercial offense shall be imposed on a legal person-a publisher who does not act as cautioned by the competent body in proceedings establishing that media pluralism has been threatened. A fine of between RSD 10,000 and 200,000 for a commercial offense referred to as previously mentioned shall be imposed on a responsible person in the publisher's company (Art. 133 of the Law on Public Information and Media).

43 Official Gazette No. 83/2014 and 6/2016.

44 Art. 1 of the Law on Electronic Media.

45 Art. 5(1)(2) of the Law on Electronic Media.

46 Media service provider means a natural or legal person who has editorial responsibility for the choice of audiovisual content of an audiovisual media service, (i.e. audio content of a radio media service) and determines the manner in which it is organized. Art. 4(1)(6) of the Law on Electronic Media.

47 Art. 22 (4-11) of the Law on Electronic Media. 
or the person responsible if their act or omission has the character of an offense punishable by law. ${ }^{48}$

Natural and legal persons, including media service providers, are eligible to submit applications to the regulator in relation to program content if they believe that the content is violating or jeopardizing their personal interests or the public interest.

The procedure for applications against media service providers is regulated by the Law on Electronic Media and detailed bylaws. What is important in the context of freedom of expression are the measures the regulator can take if it is determined that the application is reasonable. Specifically, the regulator can impose on the media service provider a remonstrance, warning, temporary ban on the publication of the program content, or may revoke their license due to a violation of obligations related to the program content, ${ }^{49}$ as well as due to a violation of the conditions set forth in the license or approval for providing media services. Those measures should be imposed independently of the use of other means of legal protection available to the injured or another party in accordance with the provisions of special laws. Since the regulator exercises public authority, it is of great importance to preserve objectivity, impartiality, and proportionality. Hence, during the process of imposing measures, the registrar is obliged to allow the media service provider to comment on the facts pertaining to the reason for the procedure. Finally, the registrar can submit a request for misdemeanor and/or criminal proceedings or initiate other proceedings before the competent state body and refer the applicant to how they can achieve and protect their rights..$^{50}$

As can be concluded from the aforementioned, the registrar has the potential to intervene in the content that can be distributed through the electronic media. However, that intervention is not censorship because it comes after the law has been breached. Moreover, if the application of the relevant provisions in practice is taken into account, it can be said that the registrar has not used their potential to the extent to which one would expect. In other words, this can provide electronic media content that is much more acceptable to the public interest of freedom of expression and freedom of information..$^{51}$ Moreover, it can be said that the main problem in the registrar's power is room for bias, since the registrar has failed to react adequately to each application. ${ }^{52}$ If the fact that the registrar's decisions and measures are under the review of the public and the court is considered, ${ }^{53}$ this problem seems to be smaller in practice.

48 Art. 24 of the Law on Electronic Media.

49 Defined in Articles 47-71 of the Law on Electronic Media.

50 Art. 26 of the Law on Electronic Media.

51 Conclusion based on decisions of the Regulator, available at: http://www.rem.rs/sr/odluke/.

52 Similar observation has been stressed in the Strategy for the Development of Public Information in the Republic of Serbia for the period 2020-2025, prepared by the Serbian Government, Official Gazette of the Republic of Serbia, No. 11/2020.

53 Art. 38-42 of the Law on Electronic Media. 


\subsection{Providing the infrastructure}

The provisions analyzed in the previous section are in relation to the media under Serbian jurisdiction. ${ }^{54}$ As regards media service providers that do not belong under the jurisdiction of Serbian law and authorities, especially social networks that are not regulated by state law, it seems impossible to control the content that is distributed among users and the public in a wider sense.

However, it is not possible to upload and distribute content on the Internet, regardless of the platforms where the information is accessible, without the physical layer of the Internet, that is, its infrastructure. ${ }^{55}$ Given those parts of the Internet infrastructure that are located within a state's territorial borders, there is only a segment of the global network over which full control can be established. By virtue of the state's sovereignty over the territory, it has certain power to regulate Internet infrastructure. This mainly derives from the regulation of electronic communications, ${ }^{56}$ but also from other areas. ${ }^{57}$ In this way, the state is also competent to indirectly regulate the Internet and the flow of data within its territory. Via regulations in the field of electronic commerce, the state regulates information society services, which are

54 A media service provider is under the jurisdiction of the Republic of Serbia if: 1) it is established in the territory of the Republic of Serbia; 2) it is not established in the territory of the Republic of Serbia, but: a) it uses a terrestrial satellite transmitting station that is located in the Republic of Serbia, and/or b) it uses satellite capacity appertaining to the Republic of Serbia. A media service provider shall be deemed to have been established in the Republic of Serbia if: 1) its head office is located in the Republic of Serbia, and its editorial decisions about media services are made in the Republic of Serbia; 2) its head office is located in the Republic of Serbia, and its editorial decisions about media services are made in another member state of the European Union, provided that a significant number of persons are employed in the Republic of Serbia (under contract of employment or otherwise) and are involved in carrying out activities related to media services; 3 ) its head office is located in the Republic of Serbia, and a significant number of persons employed under contracts of employment or otherwise involved in carrying out activities related to media services work in the Republic of Serbia and another member state of the European Union; 4) it initially commenced its activity-in accordance with the law-in the Republic of Serbia, under the condition that it maintains a stable and effective relationship with the Serbian economy and that a significant number of persons-employed under contracts of employment or otherwise involved in carrying out activities related to media services-do not work in one of the member states of the European Union; 5) its head office is located in the Republic of Serbia, and its decisions about media services are made in a country that is not a member state of the European Union, or vice versa, under the condition that a significant number of persons-employed under contracts of employment or otherwise involved in carrying out activities related to media services-work in the Republic of Serbia. If it cannot be determined whether a media service provider is under the jurisdiction of the Republic of Serbia or any other member state of the European Union, the media service provider shall be under the jurisdiction of the member state in which it was established within the meaning of Articles 56 through 58 of the Stabilization and Association Agreement concluded between the Republic of Serbia and the European Communities and their member states (Art. 45 of the Law on Electronic Media).

55 It includes, basically, cables, routers, servers, and other telecommunications devices.

56 The Law on Electronic Communication, Official Gazette of the Republic of Serbia, No. 44/2010, 60/2013, 62/2014 and 95/2018.

57 For example, laws on national security, defense, etc. 
usually provided for a fee, remotely and by electronic means, upon the request of the recipient of the service. As hosting services represent information society services, regulations in the field of e-commerce apply to the hosting company. ${ }^{58}$

\subsubsection{Jurisdiction over electronic communications}

According to the Law on Electronic Communications:

The activity of electronic communications is a regulated activity that includes the construction or installation, maintenance, use and provision of public communications networks and the provision of publicly available electronic communications services. Electronic communications network is transmission systems and switching and routing devices that enable the transmission of signals by wired, radio, optical or other electromagnetic means, including satellite networks, fixed and mobile networks. Electronic communications service is a service that is generally provided for a fee and consists of the transmission of signals in electronic communications networks, including telecommunications services and services for the distribution and broadcasting of media content. Outside the field of electronic communications, in the field of construction, the state also regulates the conditions for setting up the physical infrastructure necessary for performing the activities of electronic communications. ${ }^{59}$

Without physical infrastructure in a certain state's territory, there is neither a network nor the possibility of access. Since physical infrastructure cannot, at least legally, exist without approval, permits, and consent from state bodies, the state is able to indirectly influence other layers of the Internet through the physical one.

States most often apply their general regulations to the Internet, to the extent that their control mechanisms allow. The state has de facto control over servers, which are like computers located in its territory, where data available to the global network are stored.

Public authorities in certain situations have the authority to access and take possession of servers. As the servers are usually not owned by the persons who store data on them, but rather by private hosting companies that rent these servers to interested parties, the system of state control is reflected through regulatory competence over these companies.

Electronic surveillance is traditionally linked to state bodies such as security, internal affairs, and defense services. Those bodies, to which the highest state interests are entrusted, use operators' telecommunication means and information systems to intercept communication and access communication data. Bearing in mind that this

58 The Law on Electronic Commerce, Official Gazette of the Republic of Serbia, No. 41/2009, 95/2013 and $52 / 2019$.

59 Art. 4 of the Law of Electronic Communications. 
is a serious encroachment on citizens' right to privacy, the Constitution and laws provide for procedural guarantees and provisions that protect against abuse. The regulation that most thoroughly deals with electronic surveillance in Serbia is the Law on Electronic Communications.

Legal interception of electronic communications is the secret surveillance of telecommunication operators' electronic communications services, activities, and traffic; it is related to the content of communications and performed by authorized state bodies or organizations..$^{60}$ On the other hand, the Law on Electronic Communications introduces the obligation to retain data, as a result of which each operator is obliged to keep data on communication for a period of one year. These data do not refer to content, but rather to the type of communication, its source, destination, beginning, duration, and end, as well as data on the device through which the communication has been performed and the location of that device, so that state authorities can access them in cases provided by law. When it comes to the Internet, this practically means that all Internet communication operators are obliged to keep a whole range of data that they can collect when viewing each individual packet moving through their network, without intruding on the content of the communication.

Interception of communication and access to communication data are allowed only for a certain period of time and on the basis of a court decision, if necessary for the purpose of conducting criminal proceedings or protecting the Republic of Serbia's security, in the manner stipulated by law. ${ }^{61}$

In the described manner, Serbian authorities can achieve indirect control over the global network. Communication content is accessible to state bodies, at least in a limited number of cases. Moreover, access to Internet use data is unlimited (e.g., who, when, and at what location they accessed the network).

\subsubsection{Jurisdiction over Internet platforms}

The creator of an online platform or website's content, as well as the platform itself, can be kept on servers located in a territory different from the state to which they belong or the state from which the citizens who are the object of the content originated. Apart from that, the non-national domain is also available. This means that creators can maintain their anonymity through a registered domain system. For that reason, states may face significant obstacles in the identification process. Hence, control over content can be achieved only at the infrastructure and logical levels. ${ }^{62}$

In cases where the platform is hosted on a server outside state territory, the questions of the hosting provider's cooperation with foreign state bodies and the

60 Art. 127 of the Law of Electronic Communications.

61 Art. 130 of the Law on Electronic Communication. See also: Reljanović, 2015, pp. 113-124.

62 For example, by ordering the hosting provider to remove the content, which is not a particularly effective measure due to the fact that a skilled Internet user can re-install the removed content on a large number of servers, as well as on servers in a different jurisdictions. 
fulfillment of their requirements are also raised. Since they do not have any mechanisms to directly remove the disputed site or content or undertake some other measure in accordance with their own rules, state actions rely on international legal assistance instruments.

In cases of limited international cooperation, this can create insurmountable problems for states seeking to remove Internet content that is illegal within their jurisdiction. If the state intends to punish the platform's owner/author for violating domestic regulations, such a possibility exists if the latter has a registered or representative office in its territory. ${ }^{63}$

\subsubsection{The Internet service provider's liability in Serbian law}

An Internet service provider or intermediary provides a service connecting entities that provide information with those requesting that information. Services can have different content and are most often differentiated into three groups: mere conduit, caching, and hosting.

The most common problem emerges on a daily basis when the Internet provider enables the posting of illegal content and its sharing among users. ${ }^{64}$ In the context of this paper, this service is of great importance.

The provider does not directly commit the injury, but by providing the service, it enables the injury. The service provider's responsibility is, therefore, indirect (shared or liability of another). According to the general rules on liability, the determination of liability is grounded in the issue of conscientiousness, i.e., the question of whether the Internet provider knows or may know that copyright infringement is committed while providing the service. In other words, the provider's responsibility depends on the question of whether it applies fair trade principles while providing the service.

The technological environment in which data are exchanged, the amount of information transmitted via the Internet, and the speed of their flow are only some of the circumstances that make the assessment of conscientiousness difficult. Consequently, it is rather difficult to distinguish situations in which it has been assumed that the provider knows or could have known about the rights violation. This is especially important if the general absence of the Internet service provider's rights and obligations to supervise, i.e., control communication among users, is taken into account.

The liability of Internet intermediaries, i.e., information society service providers under the law of the Republic of Serbia, is normally regulated by the Law on Electronic Commerce.

63 The list of representatives of the biggest foreign companies that collect Serbian citizens' personal data in the course of their business activity is available at: https://predstavnici.mojipodaci.rs/. The most popular digital platforms, e.g., social networks including Facebook, Instagram, WhatsApp, and Twitter, have not identified a representative in Serbia to do that, even after several years of initiative.

64 Radanovich, 2016, pp. 157-160. 
According to this law, the intermediary is liable for the violation when it knows or could have known about service users' unauthorized actions or the content of the data and does or has not removed or disabled access to the given data immediately upon acknowledgement of an unauthorized action or data.

The obligation to monitor the content stored and exchanged via the Internet is not prescribed. However, if there is reasonable doubt that illegal actions and the exchange of illegal content are being performed by using the service, the provider is obliged to inform the competent state authority. Disclosure of user data, content removal, and disabling access to suspicious content are possible only based on a court or administrative decision. The latter directly complements the issue of liability for damage compensation. If it is assumed that guilt, as a condition of liability for damages, can be excluded when the intermediary proves that they did not act with intent or negligence, the crucial fact depends on what is considered to be negligence in providing services.

It can be imagined that the provider would prevent further infringement by disabling access to or removing unauthorized content. However, such actions can violate other entities' rights. Since the provider, in principle, has no obligation to supervise the exchanged content, the very notification of the existence of a breach instigates the provider's obligation to alert the competent authorities and act in accordance with their decisions.

In the context of liability for damages, the provider is considered liable when it has received notification of a possible infringement and fails to alert the competent authorities. Additionally, the provider can be considered liable even if, on the basis of an appropriate judicial or administrative act, it fails to provide information that is relevant for the detection of the person whose action directly caused the damage. In both cases, it is about the provider's guilt arising from its failure to act with the expected care. ${ }^{65}$

\subsubsection{Self-regulation of social networks}

In order to achieve the standards of 'good practice' and 'fair trade' when providing a networking service and, in particular, to secure the service within the safe harbor principles, social network platforms include measures and procedure in their terms of use that are applicable on the occasion of rights violations. Bearing in mind that this chapter focuses on Serbian law and given that there are no such platforms under Serbian jurisdiction (or, at least, no popular and widespread ones), the major obstacles to protecting freedom of expression, as well as rights violated by the exercise of the freedom of expression, must be mentioned.

Specifically, social network user accounts do not always identify the user who posted the content on the network. When this content is harmful, the person whose right has been violated cannot get any information about the wrongdoer without 
a decision from state authorities. In Serbia, this would mean that the Ministry of Internal Affairs should apply for international legal help in order to get the necessary data. According to the relevant United States law, such data can be obtained only when the security of a state or its citizens is endangered. In addition, when a company blocks a suspect account, although that can be helpful in some cases, the circumstances under which the decision has been made are outside of the frame of legal principles; that is, the procedure is self-organized and not transparent. Furthermore, the issues upon which the company has decided are, at their core, under the court's jurisdiction. All these circumstances leave room for bias, particularly in the sense of the unfounded rejection of the right to expression and information, i.e., information exchange.

\section{Concluding remarks}

Having observed the laws regarding freedom of expression, its restrictions, and the exchange of information, the main legal difference between social networks and media can be noted. The media are responsible for all content published in their publications, even readers' comments that are published below the texts on their online portals. The media are considered to have enough capacity to review and approve all such content. Social networks, de facto, do not and cannot have the capacity (mainly for legal reasons) to view every user post. This seems more than acceptable when it comes to freedom of expression, but it is problematic when it comes to its restriction.

Although according to the valid law of the Republic of Serbia, social networks are not media, their importance in Serbia's information sphere and on the media scene in general is becoming more pronounced. Traditional media often use influential tweeters, well-known bloggers, and Facebook statuses that have achieved high readership and been widely shared as relevant information sources, and posts on social networks are transferred to traditional media and commented on. Moreover, when celebrities comment on current socio-political circumstances, their social media publications become regular content in traditional media.

Social networks enable fast communication and information exchange. Social networks are premised upon interaction with and the expression of one's own views, comments, and contributions to discussions to other social media participants. Indeed, the term 'social networking' implies user interaction. Electronic propaganda flows uninterruptedly, since it is easier to reach the target group of users interested in certain information on social networks. Many personal profiles on social networks that are filled with certain content or information, as well as reactions to current social events, no matter how subjective, play a significant role in creating social events. 
Traditional media in Serbia still take the lead in terms of informing and creating public opinion and social trends. However, the increasingly frequent reactions of traditional media to events on social networks indicate the latter's gradual influence and their inevitable inclusion in media flows. However, social networks are not (at least, directly) encompassed under Serbian law and jurisdiction.

The direct enforcement of domestic law on the Internet is possible only where the state has sovereignty, which is expressed through territorial and personal authority over certain segments of architecture and content. ${ }^{66}$ The only way for the state to fully implement its legal system on the Internet is to take full control of the physical and logical layers. This would be a more than ambitious attempt since the Internet is a very complex environment that is further complicated by the fact that many companies providing various services within the Internet's physical and logical infrastructure are based in other countries.

On the other hand, the law leaves the possibility for the platforms themselves to remove the content that they assess as inappropriate or offensive. This means that companies cannot be accused of restricting the constitutionally guaranteed rights to freedom of speech as long as their regulation has been adequately targeted. Companies have taken advantage of this opportunity to develop algorithms for recognizing offensive or inappropriate content and eliminating it quickly. Algorithms have defects because machines still cannot replace a human's approach to editing content. This provides an additional argument that should prompt the authorities to ask for stricter rules for the regulation of social networks.

\section{Impact of 'fake news' on freedom of expression}

Misinformation concerning the politics, economics, health, and other societal spheres is probably as old as society itself. In the era preceding the media, particularly the Internet, this problem was in focus within small groups. At present, given that global network communication has intensified information exchange, making it easier and faster, the exponential increase of fake news demonstrates its potential to harm or at least endanger fundamental human rights. The fake news phenomenon has reached a new level worldwide. As such, it has been the subject of research in various areas, including law. The Serbian legal system's approach to the fake news phenomenon will be analyzed in this section. Satirical content, parody, and similar legally protected 'false' speech will be put aside in this analysis.

66 Though it is very rare in practice, the application of the Serbian law can be through the provisions of the competent law in the collision of laws. Popović and Jovanović, 2017, pp. 35-63. 


\subsection{Meaning of 'fake news'}

'Fake news' in its pure meaning warns about deception. It is the opposite of truth, reality, and fact-grounded statement. However, to simplify the global challenge of fighting fake news, the distinction between this phenomenon and disinformation as such is eliminated. The dangerous element of fake news arises from the fact that it is 'intentionally and verifiably' ${ }^{\prime 67}$ false and could impact readers, sometimes with serious consequences. For the purpose of this work, the term 'fake news' will be used to refer to the online publication of intentionally or knowingly false statements of fact. ${ }^{68}$

The major problem with fake news lies with its qualification as news. The attribute 'fake' is only subsequently ascribed, often when readers have already built their opinion or taken unlawful action (e.g., left a comment that discriminates against someone mentioned in the false story). ${ }^{69}$ There is no technical or legal means to prevent the distribution of such information. The focus is therefore on the reaction.

\subsection{Regulation of fake news in Serbia}

The social harmfulness of spreading false news in Serbia was recognized decades ago. Accordingly, the Criminal Code once contained a crime called spreading false news. This crime is committed by anyone who spreads fake news or rumors that they know to be false, with the aim of causing a serious violation of public order and peace. A person would be fined or imprisoned for up to one year for this crime, if the crime was committed through the press, radio, television, other similar media, or at a public gathering. Although the crime in this form has ceased to exist, that does not mean that spreading false news is now permissible.

\subsubsection{Criminal law concerns related to fake news}

The criminal offense has changed and has existed in the changed form since 2006 in Article 343 of the Criminal Code. The crime is entitled causing panic and disorder. This criminal offense is committed by a person who, by presenting or spreading false news or allegations, causes panic or serious disturbance of public order or peace, or thwarts or significantly hinders the implementation of decisions and measures of state bodies or organizations exercising public authority.

67 Allcott and Gentzkow, 2017, p. 213. According to this author, fake news rules out several causes: 1) unintentional reporting mistakes, 2) rumors that do not originate from a particular news article, 3) conspiracy theories (these are, by definition, difficult to verify as true or false, and they are typically originated by people who believe them to be true), 4) satire that is unlikely to be misconstrued as factual, 5) false statements by politicians, and 6) reports that are slanted or misleading but not outright false (p. 214).

68 Klein and Wueller, 2017, p. 6.

69 Colliander, 2019, p. 204. 
This criminal offense is punishable by imprisonment from three months to three years and a fine, and if the criminal offense is committed through the media or similar media or at a public gathering, a prison sentence of six months to five years is threatened. As the consequence of presenting or spreading false news, the legislator, in addition to disturbing public order and peace, also foresaw the frustration or significant obstruction of the decisions and measures of state bodies or organizations exercising public authority, and the penalties have been increased.

This does not mean that a journalist, when publishing news, must establish the absolute truth. If there was an obligation to establish the absolute truth before news could be published, it would deter journalists from publishing texts for fear of possible criminal prosecution if it happens that the news they published is not true.

Although it is not necessary to establish the absolute truth, it certainly does not release journalists from the duty to check the truthfulness of the information as required by the rules of the journalistic profession and the Code of Journalists of Serbia. This crime can be committed only with intent, which would mean that the journalist, at the time of publishing the news, has to have been aware that the information was false. If the journalist, before publishing, checks the truthfulness of the information in the manner prescribed by the Law on Public Information and Media and the Code of Journalists of Serbia, there is no awareness that the information being published is false, and therefore, this crime does not exist.

In order for this crime to exist, it is not enough that the information published is false; its publication must cause the consequences provided by the Criminal Code: panic or serious disturbance of public order or peace, or significant hindrance of the implementation of state organs' decisions and measures.

The Criminal Code stipulates that a person who transmits false news through the media or similar media or at a public gathering commits a more serious form of this crime because the false news will then be available to a larger number of people. Therefore, a more severe punishment is envisaged for the more serious form of this criminal offense. If a fake news item is published through a newspaper, radio, television, or other public medium, and the author of the fake news item is unknown or the fake news item is published without the author's consent or there are legal obstacles to prosecuting the author, as a rule, the responsible person is the editor-inchief of that medium. If these circumstances exist on the author's part, and the false news is published in an occasional printed publication, its publisher will be responsible. Under the same conditions, the manufacturer will be responsible.

\subsubsection{Civil law concerns related to fake news}

In order to protect public interest through the general and special prevention of future violations, criminal law threatens severe punishment. However, absence of the crime does not mean that human rights are not being violated. Apart from the fact that crime protection does not exclude the measures other legal areas implement, civil law provides more claims than is the case with criminal provisions. 
Based on Serbian case law, it seems that the most frequently invoked claim against fake news creators is for monetary damages. However, unlike the specific rules on damage compensation when a journalist publishes harmful content, ${ }^{70}$ when making the same request against the media due to damages caused by fake news, the general rules of the Law on Contracts and Torts are applied. The reason lies in the provisions of Art. 112 and Art. 113 of the Law of Public Information and Media, stipulating the journalist's and editor-in-chief's liability for damages.

Specifically, a person referred to in information that was prohibited to be published in accordance with this law and who suffers damages because of the publication of the information is entitled to damages to cover material and nonmaterial damages pursuant to the general regulations and provisions of this law, disregarding other means of legal protection available to said person in accordance with the provisions hereof. The right to compensatory damages also pertains to a person whose replay, correction, or other information was not published, although its publication was ordered by the competent court when that person suffered damages. Fake news is not forbidden. Hence, this specific law's liability rules do not apply.

Therefore, according to the relevant provision of the Law on Contracts and Torts, a person who causes damage to another is obliged to compensate for it, unless they prove that the damage was not caused through their own fault. ${ }^{71}$ In this respect, the Law of Public Information and Media provides an obligation of journalistic due diligence. This obligation requires that prior to publishing information about an occurrence, event, or person, both the editor and the journalist shall check its origin, authenticity, and completeness with due diligence appropriate for the circumstances. Furthermore, both the editor and the journalist shall convey the accepted information, ideas, and opinions authentically and fully, and if the information is taken from another medium, they shall credit that medium. ${ }^{72}$ In the context of fault for damage, it is hard to imagine circumstances under which the journalist could be excluded from liability.

The basis of liability is therefore the presumed fault of the person whose action caused the damage. Hence, a person who has undertaken an injurious action against someone's concrete human rights (dignity, honor, reputation) is obliged to compensate for the damage caused by their wrongdoing. However, this general rule faces enforcement obstacles with regard to fake news damages.

Primarily, there are difficulties when it comes to spreading fake news via the Internet. From the aspect of general rules, in order to succeed with a request for compensation, the damaged right holder must prove that there is a causal link between

70 Art. 112-118 of the Law on Public Information and Media.

71 Art. 154(1) Law on Contracts and Torts.

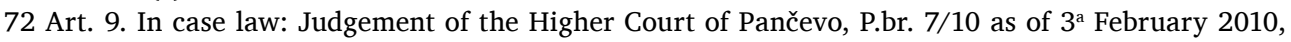
Judgement of the Higher Court of Belgrade, P3 244/14, as of 14 March 2016, Judgement of the Supreme Court of Serbia, Rev. 1477/05, as of 27 December 2005, Judgement of the Court of Appeal in Belgrade, Gž 308/2016, as of 3 February 2017, Judgement of the Higher Court in Valjevo, Gž 507/19, as of 14 May 2020, Judgement of the Court of Appeal in Novi Sad, Gž. 83/11, as of 18 January 2011. 
the false information and the damage itself. It is obvious that their position in the Internet environment where the injury occurred is far from simple. This is particularly the case when it comes to determining the origin of the misinformation. Apart from that, it is not necessary for the original source of information to be correlated with the damage caused. This could be the case when fake news is artistic, satirical, parody, or some other kind of allowed expression that is posted on a social network platform and reposted on media websites. Finally, regarding monetary compensation for non-pecuniary damages, the success of the demand, such as with respect to amount, depends on the intensity and duration of the suffering.

\subsubsection{Concluding remarks}

The above observation considered Serbian laws that could be applicable in cases involving fake news that causes legally relevant consequences. The complexity of the fake news phenomenon makes it challenging for legislatures to deal with in terms of exercising control. ${ }^{73}$ Fake news is the product of human beings, and society should deal with it through various fields of action.

In this respect, civil action can be of as much importance as authorities' actions. A major part of this is undertaken by different communities and associations that are devoted to identifying fake news, tracing its origin, and investigating liability. ${ }^{74}$ Fake news could also be suppressed through increased efforts to educate journalists, as well as through the conscience of the society itself.

From the legal point of view, it would be very problematic to define who should be the arbiter of truth.

73 During the novel coronavirus pandemic crisis in 2020, the government adopted the Conclusion on informing the population about the condition and consequences of the infectious disease COVID-19 caused by the SARS-CoV-2 virus (Official Gazette of the Republic of Serbia, No. 48/2020). The Conclusion was considered an attempt to restrict freedom of expression to the extent that it is disproportionate to the officially proclaimed goal. Thanks to the reaction of the journalistic and media community in Serbia, the controversial conclusion ceased to be effective within a short period of time.

74 For example, in Serbia: https://fakenews.rs/, where everyone could ask for the verification of the information published by the media. 


\section{Bibliography}

Allcott, H., Gentzkow, M., (2017) 'Social Media and Fake News in the 2016 Election', Journal of Economic Perspectives, 31(2), 211-236.

COLliANDER, J. (2019) “This is fake news": Investigation the role of conformity to other users' views when commenting on and spreading disinformation in social media', Computers in Human Behavior, Vol. 97, pp. 202-215.

DiligensKi, A., PRLJA, D. (2018) Fejsbuk, zaštita podataka i sudska praksa, I izdanje, Beograd, Institut za uporedno parvo.

ĐukIĆ, A. (2017) 'Krađa identiteta - oblici, karakteristike i rasprostranjenost', Vojno delo, 2017/3, pp. 99-116.

ETINSKI R. (2005) 'Doprinos Suda evropskih zajednica razvoju zabrane diskriminacije u oblasti osnovnih sloboda', Zbornik radova Pravnog fakulteta u Novom Sadu, 2005/3, pp. 325-352.

ETINSKI, D. (2004) Međunarodno javno pravo, II izdanje, Novi Sad: Pravni fakultet Univerziteta u Novom Sadu.

ETINSKI, R. (2013) 'Načelo jednakosti i nediskriminacije u pravu Republike Srbije i pravu Evropske unije: uporedna analiza', in Keča, R. (ed.) Harmonizacija srpskog i mađarskog prava sa pravom Evropske unije, pp. 51-67.

GAJIN, S. (ed.) (2010) Anti-discriminatory Laws - Guidelines, I izdanje, Beograd, Centar za unapređenje pravnih studija.

GAJIN, S. (ed.) (2015) Diskriminacija u Srbiji 2014 - izveštaj koalicija protiv diskriminacije, I izdanje, Beograd, Centar za unapređenje pravnih studija.

KLein, D.O, WuElleR, J.R. (2017) 'Fake News: A Legal Perspective', Journal of Internet Law, 2017/10, pp. 5-13.

KRŠIKAPA, M. (2008) 'Naknada štete zbog povrede ljudskih prava u praksi evropskog suda za ljudska prava', Bilten sudske prakse Vrhovnog suda Srbije, 2008/2.

Midorović, S., Sekulić, M. (2020) 'A New Function of Personal Data in the Light of the Contract for the Supply of Digital Content and Digital Services', Zbornik radova Pravnog fakulteta u Novom Sadu, 53(3), pp. 1145-1166.

MiJOviĆ, L.S. (2020) 'Internet i sloboda izražavanja u praksi Evropskog suda za ljudska prava', Zbornik radova Pravnog fakulteta u Novom Sadu, 54(3), pp. 1023-1042.

MRŠEVIĆ, Z. (2014) Zločin mržnje, govor mržnje i grafiti mržnje, I izdanje, Beograd, Kancelarija za ljudska i manjinska prava.

ORLOVIC, S. (2019) Ustavno pravo, I izdanje, Novi Sad, Pravni fakultet Univerziteta u Novom Sadu.

PETRAŠINOVIĆ, S. (2020) 'Fejsbuk I uvreda', Zbornik radova Pravnog fakulteta u Novom Sadu, 54(1), pp. 469-485.

Popović, D.V., Jovanović, M. (2017) Pravo Interneta - Odabrane teme, I izdanje, Beograd, Pravni fakultet Univerziteta u Beogradu.

RADOVANOVIĆ, S. (2015) 'Građanskopravna odgovornost internet posrednika za povredu autorskog prava - uporednopravni aspekt', in: Intelektualna svojina i Internet (ed. Popović, D.), Beograd, Pravni fakultet Univerziteta u Beogradu, pp. 113-124.

RADOVANOVIĆ, S. (2016) 'Autorsko pravo i Fejsbuk, s posebnim osvrtom na pravo Srbije', in: Intelektualna svojina i Internet (ed. Popović, D.), Beograd, Pravni fakultet Univerziteta u Beogradu, 139-164. 
RAKIĆ, I. (2014) 'Zaštita medijskog pluralizma u Srbiji prema novim zakonskim rešenjima', Zbornik radova Pravnog fakulteta u Novom Sadu, 48(3), pp. 337-349.

RAŠEVIĆ, Ž. (2014) Zabrana diskriminacije u privatnom pravu, I izdanje, Beograd, Zadužbina Andrejević.

RAŠEVIĆ, Ž. 'Nediskriminacija u prednacrtu Građanskog zakonika Srbije', Zbornik radova Pravnog fakulteta u Novom Sadu, 52(3), pp. 1297-1315.

RELJANOVIĆ, M. (2015) 'Zaštita autorskog prava i pravo na privatnost elektronskih komunikacija u Republici Srbiji', in: Intelektualna svojina i Internet (ed. Popović, D.), Beograd, Pravni fakultet Univerziteta u Beogradu, 113-124.

RELJANOVić, M., MATIĆ, M., ILIĆ, G. (2010) Priručnik za primenu antidiskriminacionog zakonodavstva, I izdanje, Beograd, Udruženje javnih tužilaca i zamenika javnih tužilaca Srbije.

ZuBČEVIĆ, A. R., BENDER, S., VOJVODIĆ, J. (2017) Regulatorna tela i govor mržnje, I izdanje, Beograd Savet Evrope, Regionalna publikacija.

ZuCKMAn, H.L., Corn-Revere, R.L, Frieden, R.M., Kennedy, C.H. (1999) Modern Communication Law, $1^{\text {st }}$ edn. Minnesota: West Academic Publishing. 